\title{
Expression of MetAP2
}

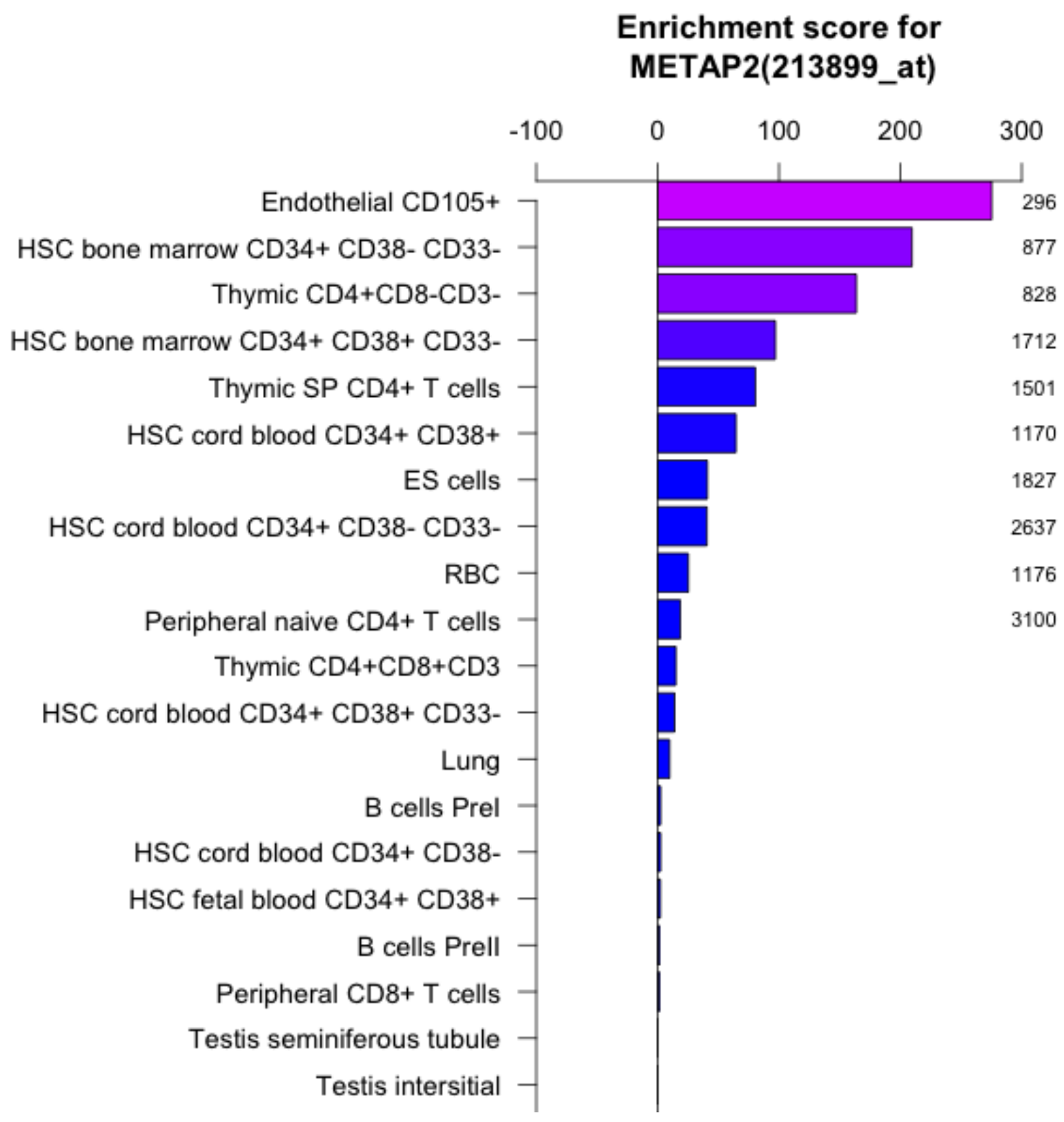

